引用格式: 杨清可, 段学军, 金志丰, 等. 长三角地区城市土地开发强度时空分异与影响机理 [J]. 资源科学, 2020, 42(4): 723734. [Yang Q K, Duan X J, Jin Z F, et al. Spatiotemporal differentiation and influencing mechanism of urban land development intensity in the Yangtze River Delta[J]. Resources Science, 2020, 42(4): 723-734.] DOI: 10.18402/resci.2020.04.11

\title{
长三角地区城市土地开发强度时空分异 与影响机理
}

\author{
杨清可 ${ }^{1}, \mathbf{E}^{\text {学军 }}{ }^{2}$ 金志丰 ${ }^{3,4}$, 王 䂞 ${ }^{2}$,王雅竹 ${ }^{2}$
}

(1. 南京财经大学公共管理学院, 南京 210023 ;2. 中国科学院南京地理与湖泊研究所, 南京 210008;

3. 武汉大学资源与环境科学学院, 武汉 430079; 4. 江苏省土地勘测规划院, 南京 210017)

摘 要: 本文基于 2000-2015 中典型年份长三角地区土地利用现状遥感监测数据,对城市土地开发强度的时 空分异与影响机理开展研究, 明确区域城市土地扩展动态与要素驱动因子。主要结论为: (1)长三角地区城市土地 开发强度指数不断增长, 2000-2015 间年均增速为 $4.20 \%$, 高于全国的 $1.28 \%$ “沪宁一沪杭一杭甬”发展的“Z”字轴 线上开发强度较高, 与社会经济发展水平相一致, 周边县市开发强度较低, “核心一外围”空间结构特征显著。(2)城 市土地开发强度在空间上表现出正的自相关性,城镇建设与工业发展沿干线路网和核心城市展开, 经济溢出与外 资注入使得外围区县的外向型产业发展极具特色, 土地开发强度的异质性高且较稳定, 布局均衡。(3)影响城市土 地开发强度变化因素中, 自然因素对城市土地开发的约束作用随着工业化推进和产业结构升级而逐渐减弱,城市 土地被高效利用, 克服基础地理限制的能力不断增强。发达的交通路网便利了生产资源的流入, 促进社会进步和 经济发展,推动了城市土地的开发, 显著提高了开发强度。同时,较高的城市行政等级在基础设施投入、人才吸引、 交通设施等方面产生虹吸效应,对城市建设用地面积需求增大,助推了城市土地开发强度的提高。

关键词: 城市土地开发强度; 时空分异; 空间相关; 影响机理; 长三角地区

DOI :10.18402/resci.2020.04.11

\section{1 引言}

城市土地资源作为人类经济活动重要的空间 载体, 是实现城市可持续发展的基本保障。在人地 矛盾突出的国情下, 土地的合理开发与空间布局是 支撑社会良性发展的必然选择, 也是未来中国城市 土地利用的重要方向 ${ }^{[1,2]}$ 。改革开放以来, 伴随城镇 化和工业化进程的深人发展, 城市土地的大规模扩 张不仅提升了土地城镇化的速度, 也带来了土地的 低效利用、边界的无序曼延、空间的结构紊乱等问 题, 有必要控制土地开发强度, 实现城市土地资源 的可持续利用 ${ }^{[3,4]}$ 。作为城市现代化水平在空间上
映射的土地开发强度, 反映着土地利用累积程度和 承载密度 ${ }^{[5]}$, 时空演变具有层次性和尺度性, 是城市 内部自然条件、社会经济、法律制度等因素彼此制 约、共同作用的结果 ${ }^{[6]}$ 。城市土地开发强度研究主 要涉及开发条件与效率、生态安全反馈与资源环境 治理等内容 ${ }^{[7]}$,决定着城市发展方向与空间开发模 式 ${ }^{[8]}$ 。因此,对城市土地开发强度的时空演变、影响 机理及其地域分异规律开展研究,成为政府与学术 界关注的焦点。

梳理已有文献,城市土地开发强度的相关研究 集中在 3 个方面: (1)从土地开发强度的测度与评价

收稿日期: 2019-07-31, 修订日期: 2019-10-25

基金项目 : 国家重点研发计划项目 (2018YFD1100101); 国家自然科学基金项目 (41601169); 南京财经大学 2019年青年学者支持计划项目 (YQKXW19001)。

作者简介:杨清可,男,山东滕州人,讲师,研究方向为区域规划与土地利用。E-mail: yangqingke66@163.com

通讯作者:段学军,男,内蒙古赤峰人, 研究员, 研究方向为区域开发与可持续发展研究。E-mail: xjduan@niglas.ac.cn 
角度切人, 以面板数据和空间分析模型为基础, 选 择典型案例, 解析土地开发强度时空演变特征 ${ }^{[0]}$ 。 运用 “ $3 \mathrm{~S}$ ”与空间分析技术, 提高土地开发强度评价 准确度 ${ }^{[5,10,11]}$, 部分研究试图运用对比方法来推演测 度土地开发强度的新方法 ${ }^{[12]}$ 。(2)城市土地开发强度 变化与驱动力分析。土地开发强度测度指标不同, 影响因素各异, 较多以容积率、建筑密度等为指标 研究其驱动机理, 影响因素呈现多样化状态, 其中 城市公共资源是土地开发强度的重要驱动因子 ${ }^{[13]}$ 。 此外,中国特殊的财政分权和城乡二元土地管理制 度, 被公认为是城市土地快速扩张的根本驱动因 素 ${ }^{[14-17]}$, 多数研究以城市土地利用扩张为主题, 从宏 观尺度上识别用地扩张方向、分析转型特点, 并构 建相应模型, 探究土地利用变化的影响机理 ${ }^{[18-20]}$ 。 (3)从土地开发强度与其他因素的相互关系等视角 展开。土地开发强度变化对资源环境的影响 ${ }^{[21,22] 、}$ 与生态多样性的作用关系 ${ }^{[23]}$ 、土地开发对生态服务

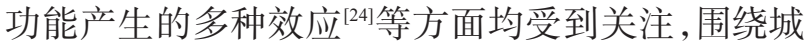
市土地开发强度与生态环境的关系开展一系列分 析。地铁干线发展对土地开发强度的影响 ${ }^{[25]}$ 、城市 空间扩展与土地开发强度演变的联系 ${ }^{[26]}$ 等方面也是 研究热点。总体来看, 在遥感解译、空间分析等技 术方法支撑下, 拓展了城市土地开发强度分析的多 维视角, 认识到土地开发格局演变与塑造力对引导 城市发展战略的重要性。目前已有成果多从评价 土地开发强度的方法出发, 侧重于进行土地利用的 时空变化特征、影响因素识别与生态环境效应等方 面的研究, 而对发达地区城市土地开发强度时空分 异与影响机理研究还需深人。

鉴于此,本文根据城市土地开发强度的内涵, 概括其变化的理论框架与构建测度模型, 对长三角 地区城市土地开发强度进行定量评估,运用空间自 相关方法解析土地开发强度时空特征; 通过对比最 小二乘法与空间误差模型的分析结果, 深人探究影 响城市土地利用强度时空分异的关键因素与驱动 机理, 有利于明确城镇化进程中土地利用的现实状 况和存在问题, 以补充土地利用变化与城市发展研 究中的相关成果。

\section{2 研究区概况、数据来源与研究方法}

\section{1 研究区概况与数据来源}

长三角地区作为 “一带一路”与长江经济带两
大国家战略的重要衔接地带, 是中国参与国际竞争 的关键平台和经济社会发展的重要引擎,在国家现 代化建设大局和开放格局中具有举足轻重的地 位。随着区域城镇化建设与工业化转型升级的深 人推进,城市土地扩张面积与开发程度逐步提高, 时空分异特征明显。同时,城市土地开发过程中存 在部分空间无序蔓延、建设侵占绿色生态空间严 重、节约集约利用程度不高等问题, 人地矛盾尖 锐。以长三角地区作为典型案例, 开展土地开发强 度的时空分异与影响机理研究, 对于协调城市土地 开发与社会经济发展具有一定实践意义,也为全国 其他地区提供新的分析视角和范例。

选取的研究范围为 “长江三角洲城市经济协调 会”内的 16 个核心成员城市,包括上海市、江苏省 8 市 （南京、镇江、常州、无锡、苏州、扬州、泰州和南通）、 浙江省 7市(杭州、宁波、嘉兴、湖州、绍兴、台州和舟 山）。以 2000 年末行政区划为基准,并进一步细分 为 82 个评价单元, 包括县、县级市和市辖区 (简称 “县市区”)。土地利用数据集来源于国家地球系统 科学数据共享平台, 运用 ENVI5.3 软件对土地利用 遥感数据进行监督解译分类, 提取并矢量化城市建 设区空间范围,以此为基础计算得到城市土地开发面 积。省界、县界、各级政府驻地、各级道路、河流等 数据来自于国家基础地理信息系统全国 1:400万数 据库 (http://nfgis.nsdi.gov.cn)。经济社会数据来源 于《中国县(市)经济社会统计年鉴》与《中国区域经 济统计年鉴》以及 2001-2016年间的《江苏统计年 鉴》《浙江统计年鉴》《上海统计年鉴》等统计资料。

\section{2 研究方法}

2.2.1 土地开发强度测度模型

土地开发强度是土地利用现状的反映、未来可 持续利用的出发点, 是表征区域范围内城市土地开 发广度与承载人口集聚能力、社会经济发展水平的 指标, 是土地生产规模、水平和特点的集中反映。 城市土地是承载人类多种活动的空间载体, 支撑和 约束城市建设和产业发展,决定区域资源潜力和环 境容量, 为城市经济增长提供基础条件。本文参考 已有研究成果 ${ }^{[4,27,28]}$, 深化对城市土地开发强度概念 的理解, 从土地开发规模 (数量)、用地层次 (结构) 与开发效率(效益)等方面综合评价长三角地区城 市土地扩张情况,测算模型为: 


$$
C L D=\frac{1}{2}\left(\frac{L B+P E+E C}{3}+\sqrt[3]{L B \times P E \times E C}\right)
$$

式中: $C L D$ 为城市土地开发强度; $L B$ 为土地开发广 度, 指建成区面积占城市总面积比重; $P E$ 为人口承 载密度, 指单位城市土地承载人口数量; $E C$ 为经济 开发力度,指单位城市土地面积的第二、三产业增 加值。对原始数据进行极差标准化处理, 采用算术 平均法和几何平均法相结合的方式计算城市土地 开发强度。

\subsection{2 空间相关分析模型}

各影响因素在空间上具有一定的异质性, 运用 探索性空间数据分析方法 (Exploratory Spatial Data Analysis, ESDA), 建立空间权重矩阵评价各单元与 周边邻域之间的关系; 借助空间滞后向量确定每个 单元的邻域状态, 探讨城市土地开发强度的空间相 关性。其中, 全局空间相关是对属性值在整个区域 空间特征的概括, 以判断某一要素或现象在空间上 是否存在分散或集聚特征, 用 Global Moran's $I$ 表 示 ${ }^{[29]}$,测算模型为:

$$
\begin{aligned}
& I=\frac{\sum_{i=1}^{n} \sum_{j=1}^{n} \boldsymbol{W}_{i j}\left(X_{i}-\bar{X}\right)\left(X_{j}-\bar{X}\right)}{S^{2} \sum_{i=1}^{n} \sum_{j=1}^{n} \boldsymbol{W}_{i j}}, \\
& \text { 其中 } S^{2}=\frac{1}{n} \sum\left(X_{i}-\bar{X}\right)^{2} ; \bar{X}=\frac{1}{n} \sum_{i=1}^{n} X_{i}
\end{aligned}
$$

式中: 当 $I<0$ 时, 表示空间负相关, $I>0$ 为空间正相 关, $I=0$ 代表空间不相关, 数值越大表示集聚程度越
强; $\boldsymbol{W}_{i j}$ 为评价单元 $i$ 和 $j$ 之间的空间权重矩阵; $X_{i} 、 X_{j}$ 分别为某属性特征在空间单元 $i$ 和 $j$ 上的表征值; $\bar{X}$ 为表征均值; $n$ 为空间评价单元总数。

局部空间相关, 用Local Moran’s I 表示。结合 Moran散点分布或LISA集聚图等方式,度量空间评 价单元 $i$ 与周边地区之间的差异程度, 可视化局部 空间格局的差异与关联规律,也被称为空间联系局 域指标 ${ }^{[29]}$ 。对于评价单元 $i$, 有:

$$
I_{i}=\frac{n\left(X_{i}-\bar{X}\right) \sum_{j=1}^{n} \boldsymbol{W}_{i j}\left(X_{j}-\bar{X}\right)}{\sum_{i=1}^{n}\left(X_{i}-\bar{X}\right)}
$$

式中: $I_{i}$ 为局部空间相关指数。

\subsection{3 影响机理的指标选取与模型构建}

(1) 分析框架与指标选取

借鉴相关文献,结合长三角地区城市土地开发 利用过程中的特殊性和数据的可获取性,将城市土 地开发强度作为因变量, 分别从自然本底条件、社 会发展水平、经济发展动力与城市竞争能力等方面 选取变量构建模型 ${ }^{[30-33]}$,探讨影响土地开发强度变 化的主要因素(图 1)。变量选择上: (1)自然本底条 件是城市土地开发基础,直接决定了可利用面积与 开发成本。条件越好, 可开发用地比重越高, 受到 耕地保护限制作用越小, 土地开发成本与扩张阻力 越小;2社会发展水平为影响土地开发的关键因 素, 承载城镇化的开展, 农业人口进城转变为城镇

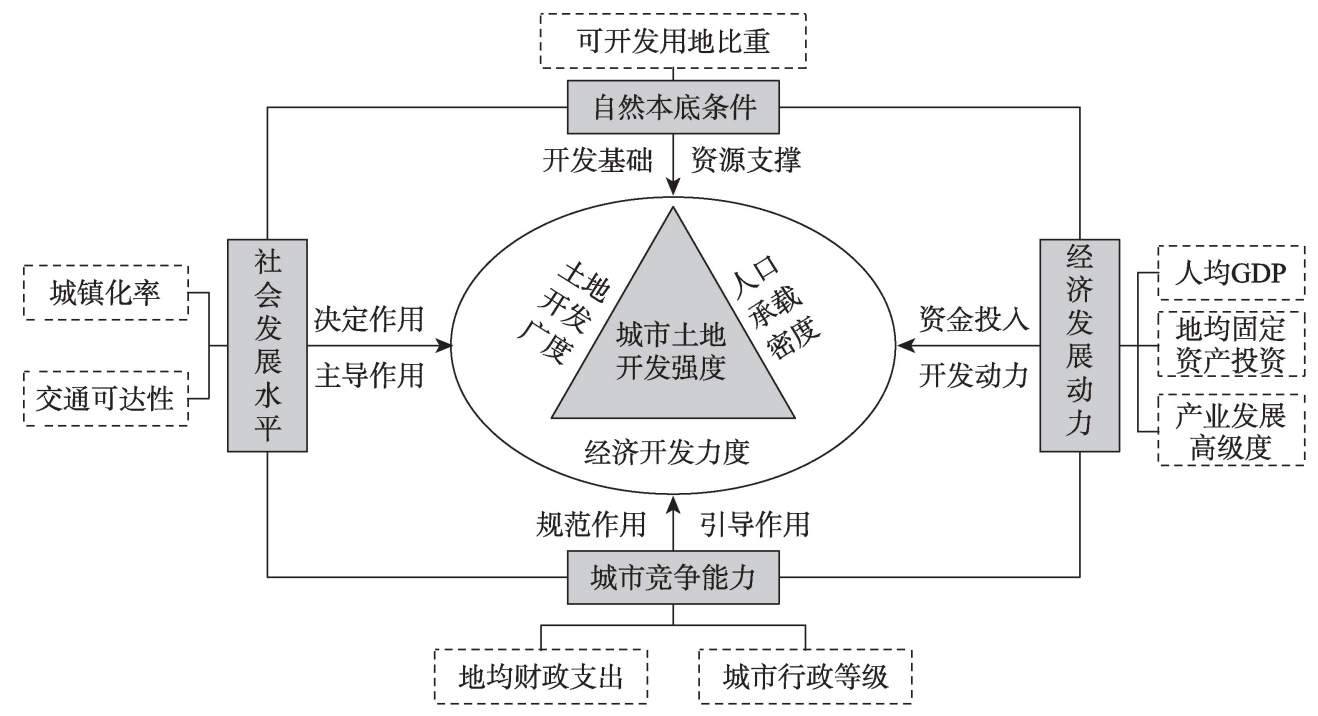

图 1 城市土地开发强度的影响分析框架

Figure 1 A theoretical framework of urban land development intensity 
居民,生活生产均需城市土地予以支撑。随着社会 发展层次的提升, 交通条件的改善, 降低土地开发 成本, 有利于城市空间扩张; (3) 经济发展增加城镇 居民收人, 改善居住条件,刺激各项生产活动的扩 大,使得城镇居住、产业发展、交通建设等活动对土 地需求旺盛, 促进土地开发。固定资产投资加快基 础设施建设, 也推动工业发展与转型升级, 土地开 发强度持续提高。此外,产业层次越高, 单位面积 城市土地产值越大, 土地利用就会越高效。(4)城市 参与市场竞争, 政府投资的基础设施、重点项目对 土地需求较大 ; 财政投人引导生产要素流动方向, 直接或间接影响土地扩张。城市行政等级与发展 定位越高, 争取资金、技术等要素的能力越强, 获得 政策支持越多。因此, 从开发利用的角度看出, 城 市土地开发强度变化是区域内自然、社会、经济、制 度等要素相互影响、共同制约的结果。最后, 考虑 影响因素性质及相关指标的多重共线性, 指标选取 如表1。

(2)模型选择与构建

为打破传统线性回归模型在结果变量空间特 征估计的局限, 同时现实中大部分经济社会问题分 析都需要考虑到空间效应, 常用的空间回归模型有 空间滞后模型 (Spatial Lag Model, SLM) 和空间误 差模型 (Spatial Error Model, SEM)。前者主要探讨 各变量在地区间是否存在溢出效应, 后者主要是探 讨误差项的空间扰动相关和空间总体相关 ${ }^{[35]}$ 。相较
普通最小二乘法 $(\mathrm{OLS})$, 选用纳人空间效应的空间 计量模型, 其回归结果更能准确反映城市土地开发 强度时空分异的影响机理在空间上的非平衡性与 变化趋势。公式如下:

$$
\begin{aligned}
& y_{t}=\rho \boldsymbol{W} y_{t}+\boldsymbol{X} \beta+\varepsilon \\
& y_{t}=\lambda \boldsymbol{W} y_{t}+\boldsymbol{X} \beta+\mu
\end{aligned}
$$

式中: $y_{t}$ 为因变量, 表示 82 个评价单元第 $t$ 年的土地 开发强度, 取对数; $\boldsymbol{W}$ 为 $n \times n$ 维空间权重矩阵, 反映 因变量自身的空间演化特征; $\boldsymbol{W} y_{t}$ 为空间一阶滞后 因变量; $\rho 、 \lambda$ 是空间回归系数; $\boldsymbol{X}$ 是由 $k$ 个外生变量 数值构成的 $n \times k$ 阶矩阵; $\beta$ 是 $k \times 1$ 阶回归系数向量; $\varepsilon$ 与 $\mu$ 是随机误差项。采用极大似然法来估计模型系 数,对前一年的因素值取对数得到自变量矩阵：

$$
X_{t-1}=\left(\begin{array}{l}
\ln \text { Dland }_{t-1}, \ln \text { DUrban }_{t-1}, \ln \text { Traffic }_{t-1}, \\
\ln \text { PGDP }_{t-1}, \ln \text { FInvest }_{t-1}, \ln \text { Indust }_{t-1}, \\
\ln \text { Finance }_{t-1}, \ln \text { Admin }_{t-1}
\end{array}\right)
$$

\section{3 结果与分析}

\section{1 城市土地开发强度的时空分异格局}

3.1.1 开发强度的时空格局演变

长三角地区城市土地开发强度指数在 2000 2015 中节点年份不断增长, 年均增速为 $4.20 \%$, 高于 全国 $1.28 \%$ 。空间布局上(图 2),城市土地开发强度 空间分异大，“核心-外围”特征显著，高值区沿“沪 宁一沪杭一杭角”交通干线呈 “Z”字型的结构特征, 与社会经济发展水平基本一致,外围县市的强度较 低。直辖市与副省级城市市区的强度高于普通地 级市区,且以上海市区、南京市区、杭州市区等最为

\begin{tabular}{|c|c|c|c|}
\hline 类型 & 指标选取 & 测算方法 & 作用方向 \\
\hline $\begin{array}{l}\text { 自然本底 } \\
\text { 条件 }\end{array}$ & 可开发用地比重 $($ Dland $) / \%$ & $\begin{array}{l}\text { 运用空间减法来计算: 可开发用地比重 }=1-\text { 不可建设土地面积 } \\
\text { (包括不可建设的湖泊河流水面、不可建设的陡岩石区等)比重-基 } \\
\text { 本农田保护面积比重-已开发用地比重 }\end{array}$ & $+/-$ \\
\hline \multirow{2}{*}{$\begin{array}{l}\text { 社会发展 } \\
\text { 水平 }\end{array}$} & 城镇化率 $($ DUrban $) / \%$ & 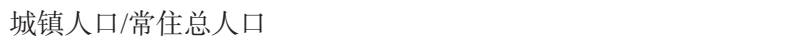 & + \\
\hline & 交通可达性 (Traffic)/km & $\begin{array}{l}\text { 依靠主要交通干线,各评价单元到中心城市 (上海、南京、杭州、苏 } \\
\text { 州、宁波)的时间和空间距离,具体测算方法参照文献[34]。 }\end{array}$ & + \\
\hline \multirow{3}{*}{$\begin{array}{l}\text { 经济发展 } \\
\text { 动力 }\end{array}$} & 人均 $\operatorname{GDP}(P G D P) /($ 万元/人) & 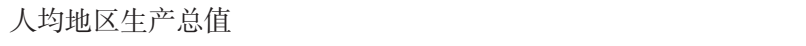 & + \\
\hline & 地均固定资产投资 (FInvest) $/\left(\right.$ 万元 $\left./ \mathrm{km}^{2}\right)$ & 固定资产投资总额/城市土地面积 & + \\
\hline & 产业发展高级度 (Indust) & $\begin{array}{l}\text { 高级度指数 }(I H)=\text { 用于度量第二、三产业相对第一产业转移的效 } \\
\text { 应 }\left(\theta_{1}\right)+\text { 第二产业向第三产业转移的效应 }\left(\theta_{2}\right)^{[25]}\end{array}$ & - \\
\hline \multirow{2}{*}{$\begin{array}{l}\text { 城市竞争 } \\
\text { 能力 }\end{array}$} & 地均财政支出 $($ Finance $) /\left(\right.$ 万元 $\left./ \mathrm{km}^{2}\right)$ & 一般公共预算支出/城市土地面积 & + \\
\hline & 城市行政等级 (Admin) & $\begin{array}{l}\text { 作为虚拟变量, 按照城市行政级别高低, 对县(县级市)、地级市、副 } \\
\text { 省级、直辖市城市分别赋值 } 1 、 2 、 3 、 4\end{array}$ & + \\
\hline
\end{tabular}

表1 影响城市土地利用强度的因素选择

Table 1 Factors affecting urban land development intensity

注: + 指正向作用; - 指逆向作用; + - 指作用方向不明确。 

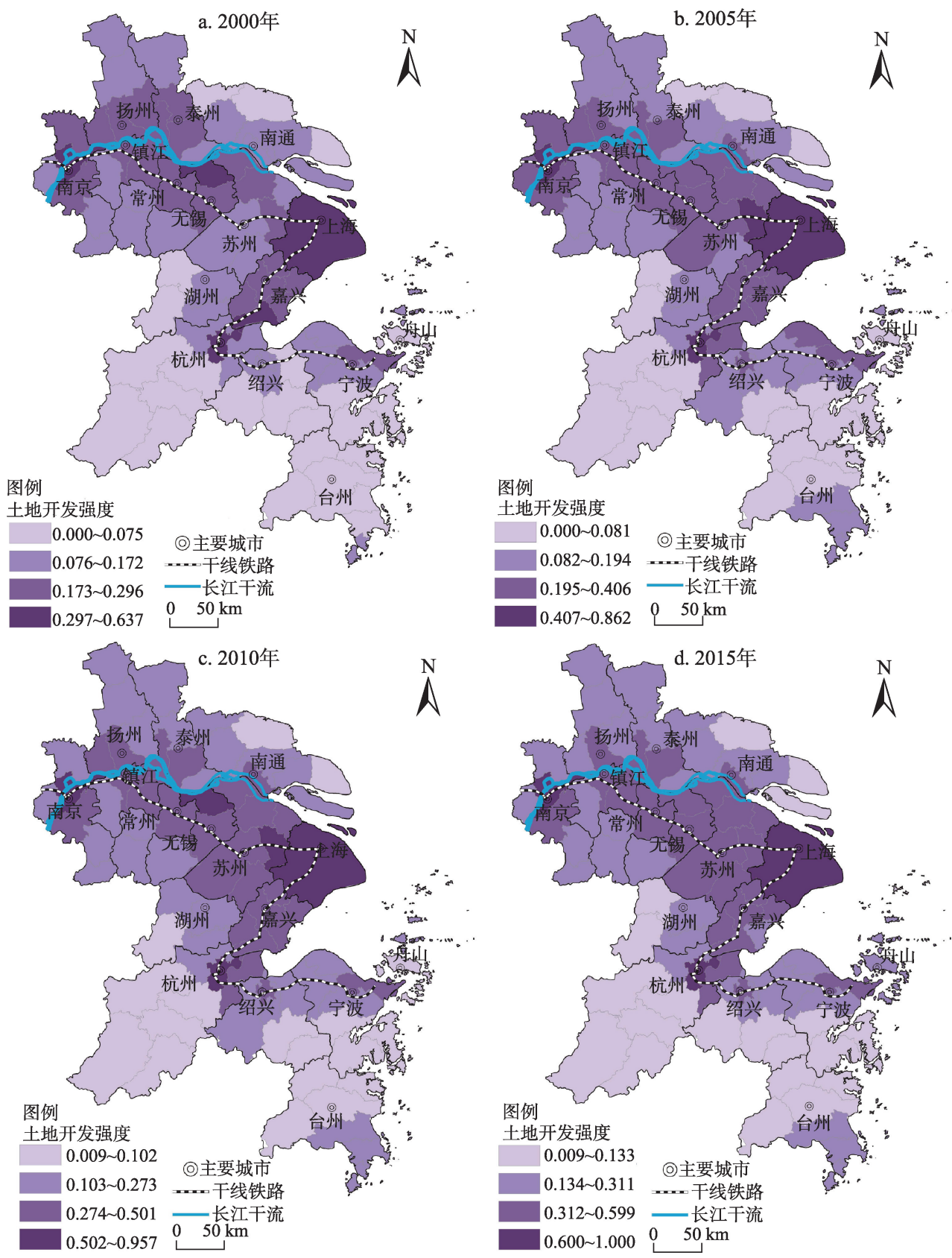

图 2 长三角地区城市土地开发强度空间分布

Figure 2 Spatial distribution of urban land development intensity

明显,行政级别高, 发展基础好, 吸引资金、技术、高 端人才等要素的成本低, 使得土地开发强度保持在 较高水平; 与此对应, 强度较低的单元主要位于浙 西北的淳安、建德、诸暨与浙中的临海、仙居、三门 等地, 受限于山地、丘陵的自然地理条件, 多被划为 生态涵养区, 产业发展受到土地供给的制约, 城市 土地开发强度较低, 与长三角地区经济水平、行政 等级与投资强度等因素吻合。

\subsection{2 开发强度的空间相关分析}

基于 OpenGeoda 软件测算长三角地区土地开 发强度全局 Moran's I 值和相关指标 (表 2)。全局 Moran's $I$ 均为正值, 通过显著性结果检验 (Z 值都 大于 1.96 的临界值), 长三角地区城市土地开发强 度存在显著正的自相关关系。由 Moran's I 值的变 化趋势可知, 2000 年长三角地区城市土地扩张主要 沿(长) 江、沿线 (沪宁铁路、沪杭铁路) 等干线路网 
表 2 长三角地区城市土地开发强度的全局空间相关

Table 2 Estimation of Moran's $I$ of urban land development intensity

\begin{tabular}{lrrrr}
\hline 指标 & \multicolumn{1}{c}{2000} & \multicolumn{1}{c}{2005} & \multicolumn{1}{c}{2010} & \multicolumn{1}{c}{2015} \\
\hline Moran’s $I$ & 0.439 & 0.340 & 0.397 & 0.394 \\
$Z(I)$ & 36.549 & 31.926 & 34.525 & 34.082 \\
$E(I)$ & 0.003 & 0.002 & 0.002 & 0.002 \\
\hline
\end{tabular}

和核心城市 (上海、南京、杭州、苏州等)展开,并在 空间上高度集聚。随着 2001 年中国加人 WTO, 作
为改革开放前沿的长三角地区, 在核心城市发展速 度持续加快的同时, 经济溢出与外资注人使得周边 区县的外向型产业发展极具特色,空间布局有所均 衡, 2005-2015 年间 Moran’s I 值有所下降,但是聚 集程度依然较高, 空间依赖性较强。

长三角地区城市土地开发强度的局域空间相 关分布见图 3 ,城市土地开发与利用格局动态变化 态势明显。2000年高-高值区主要分布于南京、嘉
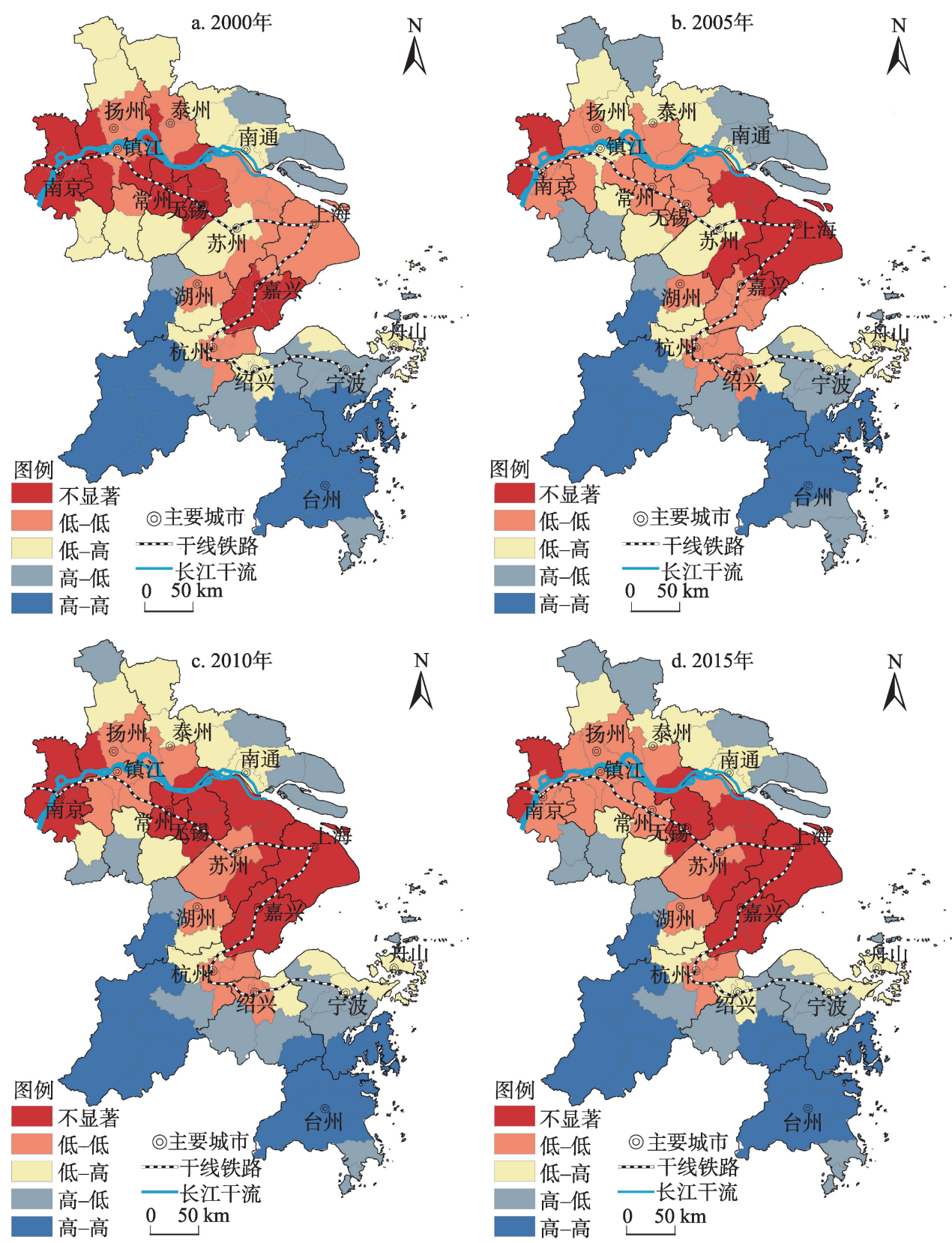

图 3 长三角地区城市土地开发强度的局域空间相关

Figure 3 Local indicators of spatial association (LISA) of urban land development intensity 
兴与苏锡常等地, 高-低值区与低-高值区呈圈层结 构依次向周边布局; 2005 年后由于城镇化与工业化 进程的推进,城市土地开发由核心城市 (上海、南 京、苏州等)不断向外围扩展, 土地开发集中连片， 高一高值区的集聚范围在工业发达的太湖流域, 城 市土地开发强度较大。苏中的北部、浙西与浙中等 地主要为低-低值区, 与城市土地开发强度的时空 格局分析对应, 土地开发一直处于较低水平, LISA 值较低, 未来经济发展应突破现有思路, 利用本地 特有的绿水青山, 发展绿色环保型经济, 实现城市 间发展优势的协调互补, 是破解地形地貌等自然条 件约束的有效途径。

\section{2 城市土地开发强度演变的影响机理}

3.2.1 OLS 模型的综合要素分析

对自然本底条件、社会发展水平、经济发展动
力与城市竞争能力等类型对应的 8 项指标变量进行 Z-score 标准化处理,运用 SPSS 软件对各因变量进 行相关性统计(表 3), 通过方差膨胀因子 (VIF) 开展 多重共线性检验,所有变量 $V I F$ 均小于 3 ,表明变量 之间不存在显著的多重共线性问题,指标选取与模 型设定较为合适。

运用 OLS 模型解析长三角地区城市土地开发 强度格局演变的影响因素,各阶段模型的拟合优度 较高,通过显著性检验, 回归结果见表 4: (1)2000年 人均 $\operatorname{GDP}(P G D P)$ 和地均固定资产投资 (FInvest) 的 回归系数分别为 0.787 和 0.973 , 表明经济发展动力 是城市土地开发强度格局演变的主导因素, 其他如 城镇化率 (DUrban)、交通可达性(Traffic) 等因素在 回归模型中系数较小。但是,此类因素在城市土地 开发中仍具有一定的促进作用,但是由经济发展驱

表 3 影响因素的相关系数矩阵

Table 3 Coefficient matrix of influencing factors

\begin{tabular}{|c|c|c|c|c|c|c|c|c|}
\hline & Dland & DUrban & Traffic & $P G D P$ & FInvest & Indust & Finance & Admin \\
\hline Dland & 1 & & & & & & & \\
\hline DUrban & 0.069 & 1 & & & & & & \\
\hline Traffic & 0.164 & 0.154 & 1 & & & & & \\
\hline$P G D P$ & 0.135 & 0.522 & 0.164 & 1 & & & & \\
\hline FInvest & -0.106 & 0.019 & 0.026 & 0.161 & 1 & & & \\
\hline Indust & 0.347 & 0.521 & 0.033 & 0.179 & 0.287 & 1 & & \\
\hline Finance & -0.403 & 0.147 & -0.114 & 0.201 & 0.081 & 0.158 & 1 & \\
\hline Admin & 0.137 & 0.168 & 0.084 & 0.073 & 0.260 & 0.142 & 0.047 & 1 \\
\hline
\end{tabular}

表 4 OLS 模型的回归估计结果

Table 4 Regression results of oridinary least squares (OLS) model

\begin{tabular}{|c|c|c|c|c|c|c|c|c|}
\hline \multirow{2}{*}{ 自变量 } & \multicolumn{2}{|c|}{2000} & \multicolumn{2}{|c|}{2005} & \multicolumn{2}{|c|}{2010} & \multicolumn{2}{|c|}{2015} \\
\hline & 系数 & Sig. & 系数 & Sig. & 系数 & Sig. & 系数 & Sig. \\
\hline 常数项 & -0.048 & 0.166 & -0.101 & 0.122 & -0.155 & 0.040 & -0.188 & 0.010 \\
\hline Dland & 0.154 & 0.000 & 0.104 & 0.024 & 0.096 & 0.106 & 0.079 & 0.225 \\
\hline Durban & 0.163 & 0.035 & 0.126 & 0.074 & 0.204 & 0.001 & 0.065 & 0.312 \\
\hline Traffic & 0.125 & 0.046 & 0.145 & 0.075 & 0.215 & 0.003 & 0.226 & 0.004 \\
\hline$P G D P$ & 0.787 & 0.011 & 1.121 & 0.000 & 0.518 & 0.000 & 0.495 & 0.000 \\
\hline Finvest & 0.973 & 0.047 & 0.435 & 0.025 & 0.425 & 0.003 & 0.343 & 0.001 \\
\hline Indust & 0.079 & 0.477 & 0.134 & 0.312 & 0.266 & 0.082 & 0.218 & 0.059 \\
\hline Finance & -0.150 & 0.790 & 0.053 & 0.883 & -0.369 & 0.020 & -0.004 & 0.963 \\
\hline Admin & 0.102 & 0.019 & 0.054 & 0.317 & 0.187 & 0.000 & 0.224 & 0.000 \\
\hline 调整 $R^{2}$ & \multicolumn{2}{|c|}{0.614} & \multicolumn{2}{|c|}{0.529} & \multicolumn{2}{|c|}{0.681} & \multicolumn{2}{|c|}{0.608} \\
\hline$F$-statistics & \multicolumn{2}{|c|}{19.183} & \multicolumn{2}{|c|}{27.308} & \multicolumn{2}{|c|}{39.344} & \multicolumn{2}{|c|}{32.732} \\
\hline Sig. & \multicolumn{2}{|c|}{0.000} & \multicolumn{2}{|c|}{0.000} & \multicolumn{2}{|c|}{0.000} & \multicolumn{2}{|c|}{0.000} \\
\hline
\end{tabular}


动与城市土地利用政策变化引起的开发强度变化 的影响程度增大; 22005-2015 年地均固定资产投 资 (FInvest) 的回归系数显著为正, 但系数值在降 低, 表明单纯依赖投资推动的城市土地开发不可持 续。可开发用地比重 (Dland) 回归系数也逐步降 低, 经济驱动与技术进步加强了人类对城市土地开 发的深度与限度, 提升了土地集约节约利用水平, 而对自然本底条件的依赖持续减弱; (3)整体看,城 市土地开发主要受社会发展水平与经济发展动力 等两大因素影响, 自然本底基础作用下降。政府通 过财政支出 (Finance) 方式引导城市土地开发的规 模、方式与方向, 摆脱依赖土地开发的发展模式; 在 中国独特的政治制度和行政体系下,城市行政等级 (Admin) 对土地开发产生促进作用,行政级别越高, 在基础设施投人、人才吸引、交通设施、教育资源等 方面产生的虹吸效应越明显。

\subsection{2 空间模型的影响机理分析}

对于空间计量模型的选择, 使用 Matlab 2015中 Spatial econometric 计量模块对所构造的模型进行 LM-Lag、LM-Error 等参数检验, 2000-2015 年长三 角地区城市土地开发强度存在显著的正向相关与 异质性, 评价单元之间的空间依赖性增强, 符合上
文第三部分的分析结果。因此选用纳人空间溢出 效应的空间误差模型 (Spatial Error Model, SEM) 来 探究城市土地开发强度演变的影响机理。OLS 模 型结果显示社会水平与经济发展为主要因素, 因 此, 在 SEM 分析中设置 3 个模型, 其中模型一(Model 1) 侧重考虑社会发展水平, 模型二(Model 2) 着重 探讨经济发展动力, 模型三 (Model 3 ) 则包含所有的 影响指标(表 5)。

(1) 自然本底条件。可开发用地比重 (Dland) 对城市土地开发的作用较低, 且不同模型中系数均 为负值, 表明自然基础条件对城市土地开发的约束 作用有限。首先, 上海、苏南、苏中与浙北地区的地 质地貌条件较好,地形起伏度小, 开发利用成本低, 能有效支撑城市扩张与工业建设对建设用地的需 求; 再者,该地区社会经济发展与科学技术水平高, 更易通过资金、技术等外力优势条件突破地形地 貌、自然灾害等客观因素对土地空间扩展的限制, 提高城市土地综合承载能力。

(2)社会发展水平。根据模型一(Model 1) 回归 结果, 城镇化率 (Durban) 驱动城市土地开发作用显 著。长三角地区社会发展水平高, 外来人口在此集 聚,推动建设用地面积快速增长。对于交通可达性

表 5 SEM 模型的回归估计结果

Table 5 Regression results of structural equation modeling (SEM)

\begin{tabular}{|c|c|c|c|c|c|c|c|c|c|c|c|c|}
\hline \multirow{2}{*}{ 自变量 } & \multicolumn{3}{|c|}{2000} & \multicolumn{3}{|c|}{2005} & \multicolumn{3}{|c|}{2010} & \multicolumn{3}{|c|}{2015} \\
\hline & Model 1 & Model 2 & Model 3 & Model 1 & Model 2 & Model 3 & Model 1 & Model 2 & Model 3 & Model 1 & Model 2 & Model 3 \\
\hline 常数项 & -0.207 & $-0.148 * *$ & -0.219 & -0.020 & -0.146 & $-0.316^{*}$ & -0.215 & $-0.229 *$ & $-0.141 * *$ & -0.318 & $-0.331^{*}$ & $-0.379 * *$ \\
\hline Dland & $0.135 * * *$ & $0.155^{* *}$ & $0.138 * * *$ & -0.015 & $0.170 * * *$ & $0.130^{* *}$ & $-0.025^{*}$ & $0.316^{* *}$ & $0.115 * *$ & 0.071 & $0.198 * *$ & 0.086 \\
\hline Durban & $0.212 * * *$ & & $0.171^{* *}$ & $0.317 * * *$ & & $0.132 *$ & $0.361 * * *$ & & $0.209 * * *$ & $0.196^{* *}$ & & $0.072 * *$ \\
\hline Traffic & $0.173 * *$ & & $0.124 * *$ & $0.355 * * *$ & & $0.151^{*}$ & $0.351 * * *$ & & $0.218^{* *}$ & $0.324 * * *$ & & $0.231 * *$ \\
\hline$P G D P$ & & $1.007 * *$ & $0.769 * *$ & & $1.338^{* *}$ & $1.127 * *$ & & $0.661 * * *$ & $0.515^{*}$ & & $0.563 * *$ & 0.501 \\
\hline Finvest & & $0.926^{*}$ & $0.937 *$ & & $0.429 * * *$ & $0.431 * *$ & & $0.503 * *$ & $0.441 * *$ & & $0.313 * *$ & 0.348 \\
\hline Indust & & $0.222 * *$ & 0.092 & & 0.186 & 0.140 & & $0.515^{* *}$ & $0.302 * *$ & & $0.299 * *$ & $0.224 * *$ \\
\hline Finance & 0.510 & & 0.164 & $0.208^{*}$ & & 0.059 & $0.028^{* *}$ & & $0.089 * * *$ & $0.108^{*}$ & & 0.012 \\
\hline Admin & $0.103 *$ & 0.124 & 0.102 & $0.115^{*}$ & $0.097 * *$ & 0.058 & $0.200^{* *}$ & $0.163 * *$ & 0.188 & $0.348 * *$ & $0.209 * * *$ & $0.228 * * *$ \\
\hline Lambda & -0.233 & -0.181 & -0.150 & $-0.422 * *$ & -0.017 & -0.001 & -0.239 & -0.204 & -0.224 & -0.142 & -0.117 & -0.014 \\
\hline$R^{2}$ & 0.608 & 0.606 & 0.653 & 0.535 & 0.693 & 0.723 & 0.662 & 0.718 & 0.788 & 0.767 & 0.722 & 0.755 \\
\hline $\operatorname{LOG} L$ & 106.686 & 106.549 & 112.252 & 70.896 & 90.347 & 94.935 & 75.818 & 84.107 & 97.158 & 90.769 & 78.165 & 84.077 \\
\hline$L R$ Test & 0.237 & -0.013 & -0.006 & 0.232 & 0.039 & 0.045 & 0.279 & -0.011 & -0.021 & 0.004 & 0.007 & 0.040 \\
\hline$A I C$ & -201.602 & -193.202 & -207.650 & $-130.939-$ & -169.841 & -173.015 & -140.781 & -157.360 & -177.463 & -106.684 & -145.475 & -151.300 \\
\hline$S C$ & -188.002 & -187.803 & -185.990 & -116.499 & -155.401 & -151.355 & -126.341 & -142.919 & -155.802 & -92.244 & -131.035 & -129.640 \\
\hline
\end{tabular}

注: $* * * * *$ 和*分别表示 $1 \% 、 5 \%$ 和 $10 \%$ 的显著性水平。 
(Traffic)，良好的交通路网条件加快了人流、物流的 空间移动, 降低了土地利用过程平整与规避自然灾 害的成本, 促进城市土地开发。2000年时交通条件 的作用强度与方向的异质性不明显,但 2005 年后, 交通条件对城市土地开发的影响强度逐步增强, 各 城市开始注重由交通路网建设带来的基础设施投 资的增加,进而促进社会发展的繁荣; 尤其在 2010、 2015 年, 随着高速铁路的建设与组网, 长三角地区 依靠自身在区域一体化发展过程中累积的先发优 势, 在城市袭夺与城市群的虹吸作用下, 为人力、技 术等要素资源的流人提供便利, 助推城市土地空间 扩张与开发强度的提升。

(3) 经济发展动力。人均 $\operatorname{GDP}(P G D P)$ 对城市 土地开发的影响最为显著, 经济发展加速土地城镇 化进程, 是城市土地扩张的最大驱动因素, 与已有 研究成果相符合 ${ }^{[36]}$ 。用地投资强度也是影响城市土 地开发强度变化因素之一, 地均固定资产投资 (FIn$v e s t$ ) 的回归系数为正值, 在 $5 \%$ 水平上显著, 表明单 位面积城市土地利用上投人越高, 集聚越多的产业 工人、企业等要素, 越能高效开发土地资源, 为经济 发展提供优质空间载体, 提高土地利用的产出效 益。产业结构水平 (Indust) 对城市土地开发强度的 空间演变也产生一定影响,城市土地开发为工业、 服务业等二、三产业的发展提供支撑, 工业发展与 开发区的大量设立均对建设用地产生较大需求, 使 得长三角地区城市土地开发强度快速提高。

(4)城市竞争能力。从地均财政支出 (Finance) 的回归系数变化来看, 2000-2015 年为正值, 但不 是很高, 提升土地开发强度的作用弱, 表明单纯依 靠政府财政投资促进城市发展的时代已经成为过 去, 城市土地开发更应尊重市场, 利用经济因素琵 动城市发展。城市本身能量高低对土地扩张仍起 到一定作用, 表 5 显示城市行政等级 (Admin) 对城市 土地开发强度演变的影响程度不断加大, 系数值由 2000 年的 0.103 增至 2015 年的 0.348 , 说明不同城市 行政级别所带来的政策、人才、技术等要素集聚的 差异。级别高的城市享有包括物资供应、资金和生 产资料等资源配置便利, 对要素的吸引具有天然优 势。在经济发展中拥有更好的投资立项、税收优 惠、土地征用等政策, 对城市土地开发产生越发显
著的推动作用。

\section{4 结论与讨论}

基于 2000-2015 年长三角地区土地利用现状 遥感监测数据, 本文综合运用空间分析、多元回归和 空间误差模型等的方法,分析了长三角地区城市土 地开发强度的时空分异与影响机理, 主要结论为:

(1) 长三角地区城市土地开发强度在 2000 2015 年间不断增长, 2000 年土地开发强度为 0.089 , 2015 年增至 0.165 , 高于全国同期 0.046 的平均水 平。空间分异显著, “核心一外围”特征明显, 较高 水平的单元集中于“沪宁一沪杭一杭甬”发展的“Z 字”轴线上,基本上与社会经济发展水平相一致,且 以平原为主, 河网纵横, 交通便利, 开发成本低, 能 保障快速城镇化与工业化发展对建设用地的需 求。周边县市受到核心城市的虹吸效应影响,集聚 资本、人才与技术等要素能力低, 土地开发广度与 深度受到限制, 土地开发强度相对较低。

(2)长三角地区城市土地开发强度在空间上表 现出正的自相关性,城镇建设与工业发展主要在沿 (长)江、沿线 (沪宁铁路、沪杭铁路)等干线路网和 核心城市 (上海、南京、杭州、苏州等) 展开,空间上 高度集聚, 是城市空间扩张与经济发展的重要方 向。加人WTO后, 长三角地区城市发展层次提高, 经济溢出与外资注人使得周边区县外向型产业发 展极具特色,城市之间依靠比较优势, 共享要素资 源, 实现产业分工, 提高了整体竞争力。

(3)长三角地区自然本底条件承载生产、生活 活动引起城市空间扩张, 对土地开发的约束作用减 弱,由自然条件约束等地理要素向社会经济发展影 响转变,社会水平与经济发展成为推动城市土地开 发强度提高的关键因素, 快速城镇化集聚大量外来 人口, 发达的交通路网降低城市建设与产业发展成 本; 工业化的深度进行和产业的转型升级,集聚人 才、技术、资本等高端生产要素,促进城市土地高效 开发, 为经济发展提供优质载体, 提升土地利用效 益。城市行政等级对土地开发具有促进作用,级别 越高,在基础设施投人、人才吸引、教育资源等方面 产生的集聚效应就越显著。

在区域一体化、经济市场化深人推进的背景 下,长三角地区很大程度上依赖“土地财政”促进城 
市发展与土地扩张, 这种模式伴随城市土地减量化 规划、基本农田与环境保护等政策的落实, 发展空 间不断缩小,迫切需要地方政府在控制土地开发总 量的前提下,探索开发的新模式与优化的新路径, 加强城市土地节约集约利用水平, 提高土地开发的 质量与效益。城市土地开发强度变化具有一定的 系统复杂性, 本文通过评价城市土地开发强度, 构 建探究驱动机理的理论分析框架,解析长三角地区 城市土地开发强度的时空分异与影响机理,但是城 市土地开发强度的空间异质性是多因素、多尺度相 互作用的结果,评价单元间的时空分异明显。因 此, 在今后的研究中, 应根据城市发展独特属性与 土地开发实际情况, 采用多元、多层次的模型方法 对土地开发强度的格局演变与驱动机理开展分析。

\section{参考文献(References):}

[1] Byomkesh T, Nakagoshi N, Dewan A M. Urbanization and green space dynamics in Greater Dhaka, Bangladesh[J]. Landscape \& Ecological Engineering, 2012, 8(1): 45-58.

[2] 刘浩, 张毅, 郑文升. 城市土地集约利用与区域城市化的时空耦 合协调发展评价: 以环渤海地区城市为例[J]. 地理研究, 2011, 30(10): 1805-1817. [Liu H, Zhang Y, Zheng W S. Evaluation on spatio-temporal development and interaction of intensive urban land use and urbanization: Case studies of the cities in the Bohai Rim Region[J]. Geographical Research, 2011, 30(10): 1805-1817.]

[3] 王宏亮. 城镇化背景下建设用地利用强度研究: 以内蒙古为例 [D]. 北京: 中国农业大学, 2017. [Wang H L. Research on Construction Land Use Intensity in Urbanization: A Case Study in Inner Mongolia[D]. Beijing: China Agricultural University, 2017.]

[4] 杨清可, 段学军, 李平星, 等. 江苏省土地开发度与利用效益的 空间特征及协调分析[J]. 地理科学, 2017, 37(11): 1696-1704. [Yang Q K, Duan X J, Li P X, et al. The spatial pattern and coordination analysis between degree of land development and use benefit in Jiangsu[J]. Scientia Geographica Sinica, 2017, 37(11): 16961704.]

[5] 张竞珂, 陈逸, 黄贤金. 长江经济带土地开发均衡度及限度评价 研究 [J]. 长江流域资源与环境, 2017, 26(12): 1945-1953. [Zhang J K, Chen Y, Huang X J. Assessment of the equilibrium degree and limitation degree of Yangtze River Economic Belt's land development[J]. Resources and Environment in the Yangtze Basin, 2017, 26(12): 1945-1953.]

[6] 赵亚莉, 刘友兆, 龙开胜. 长三角地区城市土地开发强度特征及 影响因素分析[J]. 长江流域资源与环境, 2012, 21(12): 1480-
1485. [Zhao Y L, Liu Y Z, Long K S. Features and influencing factors of development intensity of urban land resources in the Yangtze River Delta[J]. Resources and Environment in the Yangtze Basin, 2012, 21(12): 1480-1485.]

[7] 岳文泽, 章佳民, 刘勇, 等. 多源空间数据整合视角下的城市开 发强度研究[J]. 生态学报, 2019, 39(21): 7914-7926. [Yue W Z,

Zhang J M, Liu Y, et al. Measuring urban development intensity based on the integration of multi-source spatial data[J]. Acta Ecologica Sinica, 2019, 39(21): 7914-7926.]

[8] 周敏, 匡兵, 陶雪飞. 空间收玫视角下中国城市土地开发强度演 变特征[J]. 经济地理, 2018, 38(11): 98-103. [Zhou M, Kuang B, Tao X F. Evolution characteristics of urban land development intensity in china from the perspective of spatial convergence[J]. Economic Geography, 2018, 38(11): 98-103.]

[9] Ferdous N, Bhat C R. A spatial panel ordered-response model with application to the analysis of urban land-use development intensity patterns[J]. Journal of Geographical Systems, 2013, 15(1): $1-29$.

[10] Di X H, Hou X Y, Wang Y D, et al. Spatial-temporal characteristics of land use intensity of coastal zone in China during 20002010[J]. Chinese Geographical Science, 2015, 25(1): 51-61.

[11] 张苗, 甘臣林, 陈银蓉, 等. 中国城市建设用地开发强度的碳排 放效率分析与低碳优化[J]. 资源科学, 2016, 38(2): 265-275. [Zhang M, Gan C L, Chen Y R, et al. Carbon emission efficiency and optimization of low carbon for construction land development intensity in China according to provincial panel data[J]. Resources Science, 2016, 38(2): 265-275.]

[12] Erb K H, Fetzel T, Haberl H, et al. Beyond Inputs and Outputs: Opening the Black- Box of Land-Use Intensity[A]. Haberl H, Fischer-Kowalski M, Krausmann F, et al. Social Ecology: SocietyNature Relations across Time and Space[M]. Basel: Springer, 2016.

[13] 谭少华, 张青, 姜骁, 等. 正反双重因素导向下的土地开发强度 研究: 以习水县城市总体规划为例 [J]. 西部人居环境学刊, 2013, (6): 64-70. [Tan S H, Zhang Q, Jiang X, et al. A study on land development intensity guided by the positive and negative factor: Illustrated by the case of Master Plan of Xishui County[J]. Journal of Human Settlements in West China, 2013, (6): 64-70.]

[14] 陈浩, 张京祥, 陈宏胜. 新型城镇化视角下中国“土地红利”开发 模式转型[J]. 经济地理, 2015, 35(4): 1-8. [Chen H, Zhang J X, Chen H S. The transformation of land dividend under the perspective of new urbanization[J]. Economic Geography, 2015, 35(4): 1-8.]

[15] 田莉. 处于十字路口的中国土地城镇化: 土地有偿使用制度建 立以来的历程回顾及转型展望[J]. 城市规划, 2013, 37(5): 2228. [Tian L. Land urbanization of china at the cross road: A review on the evolution since the establishment of land use right system 
and the prospect of its transformation[J]. City Planning Review, 2013, 37(5): 22-28.]

[16] Lin G C S. China's landed urbanization: Neoliberalizing politics, land commodification, and municipal finance in the growth of metropolises[J]. Environment and Planning A, 2014, 46(8): 18141835 .

[17] He C F, Yi Z, Huang Z J. Fiscal decentralization, political centralization, and land urbanization in China[J]. Urban Geography, 2016, 37(3): 436-457.

[18] Lin G C S. Reproducing spaces of Chinese urbanisation: New citybased and land-centred urban transformation[J]. Urban Studies, 2007, 44(9): 1827-1855.

[19] 刘彦随, 杨忍. 中国县域城镇化的空间特征与形成机理[J]. 地理 学报, 2012, 67(8): 1011-1020. [Liu Y S, Yang R. The spatial characteristics and formation mechanism of the county urbanization in China[J]. Acta Geographica Sinica, 2012, 67(8): 10111020.]

[20] 李进涛, 刘彦随, 杨园园, 等. 1985-2015 年京津冀地区城市建 设用地时空演变特征及驱动因素研究[J]. 地理研究, 2018, 37 (1): 37-52. [Li J T, Liu Y S, Yang Y Y, et al. Spatial-temporal characteristics and driving factors of urban construction land in Beijing-Tianjin-Hebei region during 1985-2015[J]. Geographical Research, 2018, 37(1): 37-52.]

[21] 赵亚莉, 刘友兆, 龙开胜. 城市土地开发强度变化的生态环境效 应[J]. 中国人口・资源与环境, 2014, 24(7): 23-29. [Zhao Y L, Liu Y Z, Long K S. Eco-envionmental effects of urban land development intensity change across capital cities in China[J]. China Population, Resources and Environment, 2014, 24(7): 23-29.]

[22] Yan H M, Liu F, Liu J Y, et al. Status of land use intensity in China and its impacts on land carrying capacity[J]. Journal of Geographical Sciences, 2017, 27(4): 387-402.

[23] Meerbeek K V, Helsen K, Hermy M. Impact of land-use intensity on the conservation of functional and phylogenetic diversity in temperate semi-natural plant communities[J]. Biodiversity \& Conservation, 2014, 23(9): 2259-2272.

[24] Xu Y, Tang H P, Wang B J, et al. Effects of land-use intensity on ecosystem services and human well-being: A case study in Huailai County, China[J]. Environmental Earth Sciences, 2016, doi: 10. 1007/s12665-015-5103-2.

[25] 周艳, 黄贤金, 徐国良, 等. 长三角城市土地扩张与人口增长耦 合态势及其驱动机制 [J]. 地理研究, 2016, 35(2): 313-324. [Zhou Y, Huang X J, Xu G L, et al. The coupling and driving forces between urban land expansion and population growth in Yangtze River Delta[J]. Geographical Research, 2016, 35(2): 313-324.]
[26] Zhang Z X, Wen Q K, Liu F, et al. Urban expansion in China and its effect on cultivated land before and after initiating " "Reform and Open Policy”[J]. Science China(Earth Science), 2016, 59(10): 1930-1945

[27] 陈逸. 区域土地开发度评价理论、方法与实证研究 $[D]$. 南京: 南 京大学, 2012. [Chen Y. The Assessment of the Degree of Regional Land Development: Theory, Methods and Empirical Research [D]. Nanjing: Nanjing University, 2012.]

[28] 刘艳军, 于会胜, 刘德刚, 等. 东北地区建设用地开发强度格局 演变的空间分异机制[J]. 地理学报, 2018, 73(5): 818-831. [Liu Y J, Yu H S, Liu D G, et al. Spatial differentiation mechanisms of the pattern evolution of construction land development intensity in Northeast China[J]. Acta Geographica Sinica, 2018, 73(5): 818-831.]

[29] 张琳琳. 转型期中国城市蔓延的多尺度测度、内在机理与管控 研究[D]. 杭州: 浙江大学, 2018. [Zhang L L. Research on the Urban Sprawl in Transitional China: Multi-Scale Measurement, Mechanism, and Remedies[D]. Hangzhou: Zhejiang University, 2018.]

[30] 蔡芳芳, 誉励杰. 南通市城乡建设用地演变时空特征与形成机 理[J]. 资源科学, 2014, 36(4): 731-740. [Cai F F, Pu L J. Spatialtemporal characteristics and formation mechanism of urban-rural construction land in Nantong City[J]. Resources Science, 2014, 36 (4): 731-740.]

[31] Li H, Wei Y D, Liao F H, et al. Administrative hierarchy and urban land expansion in transitional China[J]. Applied Geography, 2015, 56: 177-186.

[32] Chen J L, Gao J L, Chen W. Urban land expansion and the transitional mechanisms in Nanjing, China[J]. Habitat International, 2016, 53(4): 274-283.

[33] Yang Q K, Duan X J, Lei W. Spatial-temporal patterns and driving factors of rapid urban land development in Provincial China: A case study of Jiangsu[J]. Sustainability, 2017, 9(12): 2371-2386.

[34] 杨光辉, 张冬有. 基于 GIS 的黑龙江省市域交通可达性分析[J]. 测绘与空间地理信息, 2019, 42(3): 58-60. [Yang G H, Zhang D Y. City in transportation accessibility analysis level in Heilongjiang Province based on GIS[J]. Geomatics \& Spatial Information Technology, 2019, 42(3): 58-60.]

[35] 王劲峰, 廖一兰, 刘釒金. 空间数据分析教程[M]. 北京: 科学出版 社, 2010. [Wang J F, Liao Y L, Liu X. Spatial Data Analysis Course[M]. Beijing: Science Press, 2010.]

[36] 盛业旭. 经济增长与城市土地扩张脱钩[D]. 南京: 南京农业大 学, 2015. [Sheng Y X. Decoupling of Economic Growth and Urban Land Expansion: Measure, Influence Factors and Control Strategy [D]. Nanjing: Nanjing Agricultural University, 2015.] 


\title{
Spatiotemporal differentiation and influencing mechanism of urban land development intensity in the Yangtze River Delta
}

\author{
YANG Qingke ${ }^{1}$, DUAN Xuejun², JIN Zhifeng ${ }^{3,4}$, WANG Lei², WANG Yazhu² \\ (1. School of Public Administration, Nanjing University of Finance \& Economics, Nanjing 210023, China; 2. Nanjing Institute of \\ Geography and Limnology, CAS, Nanjing 210008, China; 3. School of Resource and Environmental Science, Wuhan University, \\ Wuhan 430079, China; 4. Jiangsu Institute of Land Surveying and Planning, Nanjing 210017, China)
}

\begin{abstract}
Urban land development intensity is a comprehensive reflection of the present situation of land use and the starting point of sustainable utilization in the future. It is also a comprehensive index reflecting the breadth of urban land development and carrying capacity of population and social and economic development. Based on the remote sensing monitoring data of land use in the Yangtze River Delta from 2000 to 2015, this study examined the spatiotemporal differentiation and influencing mechanism of urban land development intensity by using spatial analysis, multiple regression, and spatial error regression models, in order to improve land use efficiency and environmental quality. The main conclusions are as follows: (1) The index value of urban land development intensity in the Yangtze River Delta had been increasing from 0.089 in 2000 to 0.165 in 2015, which is higher than the national average of 0.046 in the same period. The development intensity of the " $Z$ " axis of the Nanjing- Shanghai- Hangzhou- Ningbo area is higher than the regional average, which is consistent with the level of social and economic development. The development intensity of surrounding counties and cities is relatively low, and the spatial structure of core-periphery is remarkable. (2) Urban land development intensity shows a positive spatial correlation. Urban construction and industrial development are based on trunk transportation network and core urban areas. Economic spillover and foreign capital injection make the exportoriented economic development of surrounding counties very distinctive. The heterogeneity of land development intensity is high and relatively stable, and the spatial layout gradually reaches equilibrium step by step. However, the correlation gradually weakened in time. (3) The constraints of natural conditions on urban land development are weakening, and the deep industrialization and transformation and upgrading of industrial structure lead to efficient urban construction land development. Urbanization gathers a large number of immigrants, and the construction of highly developed transportation network facilitates the inflow of talent, capital, technology, and other essential resources. Both the level of social development and the force of economic development have become important factors that promote the enhancement of regional land development intensity. Meanwhile, the spatial agglomeration effect of higher urban administrative level in infrastructure investment, talent attraction, transportation facilities, and other aspects also promotes the large-scale development of urban land.
\end{abstract}

Key words: urban land development intensity; spatiotemporal differentiation; spatial association; influencing mechanism; Yangtze River Delta 